\title{
Political Agroecology in Mexico: A Path toward Sustainability
}

\author{
Víctor M. Toledo ${ }^{1, *}$ and Narciso Barrera-Bassols ${ }^{2}$ \\ 1 Instituto de Investigaciones en Ecosistemas y Sustentabilidad, \\ Autonomous National University of Mexico (UNAM), Morelia, Michoacán 58190, Mexico \\ 2 Facultad de Ciencias Políticas y Sociales, Autonomous University of Querétaro, \\ Santiago de Querétaro 76017, Mexico; barrera@itc.nl \\ * Correspondence: vtoledo@cieco.unam.mx; Tel./Fax: +52-443-3222735
}

Academic Editors: Manuel González de Molina and Gloria Guzman Received: 12 December 2016; Accepted: 7 February 2017; Published: 14 February 2017

\begin{abstract}
The biocultural richness of Mexico is among the highest worldwide. A history of over 7000 years of agriculture, and a persistent tradition of peasant social resistance movements that climaxed during the agrarian revolution in the early 20th century, continued in the indigenous resistance in Chiapas leading to the Zapatista uprising in 1992, and continues to be expressed in present local and regional confrontations for the defense of territory. Scholars agree that agroecology conceptually includes ecological and agricultural scientific research activity, empirical practices applied for agriculture, and the nuclear goal of numerous rural social movements. What has not been sufficiently established is how these three spheres of agroecology interact with each other and what emergent synergies they generate. Taking as an example the production in Mexico of three key agricultural goods-maize, coffee, and honey-our paper briefly reviews the existing relations between knowledge generation, agroecological practices, and rural social processes. We conclude by reflecting on the role of agroecological research in the context of an agrarian sustainability committed to helping reduce social inequity, marginality, and exploitation, as much as reverting the severe deterioration of the natural environment: both common issues in contemporary Mexico.
\end{abstract}

Keywords: agroecology; agrarian sustainability; maize; coffee; honey-bee; Mexico

\section{Introduction}

Agroecology is an emerging field of knowledge involved in offering solutions to the serious environmental and food production problems incited by modern or industrialized agriculture and agribusiness in the entire world [1]. As a hybrid discipline, agroecology adopts a multi-disciplinary scope: As a post-normal science, it seeks to be not only applied knowledge but also an example of participatory research, and as a form of critical thinking, agroecology engages in contesting social inequity as much as environmental disturbances. Scholars agree on agroecology conceptually including three spheres or dimensions as a sort of holy trinity: ecological and agricultural scientific research, empirical practices applied for agriculture, and an objective of seeding numerous rural social movements [2-4].

While scientific and practical dimensions of agroecology refer to cognitive and technological fields, respectively, the third dimension is linked to the social movements and political actions of agrarian communities. As pointed out by Rosset and Martinez-Torres [5], many actors including peasants, rural households, indigenous people, rural landless workers and women, among others, use agroecology as a tool for the contestation and defense of their territories and natural resources, their lifestyles, and their biocultural heritages. 
In Latin America in general, the practice of agroecology involves scientific and technological research made in close relation to rural social and political movements, a trend that has experienced an unprecedented expansion and multiplication in many countries of the region [6-8]. Agroecology is practiced by tens of thousands of peasant households in Latin America as a result of either social movements or implementation of public policies, with extraordinary advances in Brazil, Cuba, Nicaragua, El Salvador, Honduras, México, and Bolivia, and with moderate achievements in Argentina, Venezuela, Colombia, Peru, and Ecuador. It therefore can be said that the dominant trend of agroecology in Latin America is political agroecology, understood as the practice of agroecology acknowledging that agrarian sustainability cannot be achieved simply by technological innovations of environmental or agronomic nature, but also by a much-needed institutional change in power relations, i.e., by taking into account social, cultural, agricultural, and political factors [9].

The several approaches and perspectives of agroecology as a science, which imply an ample diversity of interpretations and applications, have been extensively discussed and debated in recent years (see for instance several chapters of a recent book [10]), including its legitimacy and suitability in the heterogeneous world's food system [11]. Moreover, some authors define agroecology as a transdisciplinary, participatory, and action-oriented approach [12], and many more of them consider agroecology as a new expression of PAR (Participatory Action-Research) [13], that emerged through the work carried out by Third World social scientists since more than three decades ago, and as an innovative approach promoting social change [14]. However, none of them have paid attention to the links and interactions between the three spheres of agroecology until now.

With the aim of contributing to the understanding of the synergies generated through the interaction of the above-mentioned three spheres or dimensions involved in agroecology, in this paper we make a brief review of political agroecology in Mexico. Our hypothesis is that as social movements stimulate the advance of scientific and technological research, social rural sectors are reciprocally benefiting from scientific and technological innovations in a sort of a co-evolutionary process, or as a co-production of scientific/technological and local "knowledge thoughts" and practice $[15,16]$. In order to test our hypothesis, we here examine three key sectors of small-scale peasant agroecological production in the country: the milpa system of producing maize as a polyculture, the shade-grown coffee agroforestry systems, and honey production systems.

\section{The Mexican Agrarian Context}

Most of the world's agricultural production continues to be practiced by peasants, or small-scale traditional farmers, whose knowledge and practices are the product of over 10,000 years of tradition $[17,18]$. The fact has been corroborated by recent studies made by the FAO showing that the bulk of the foodstuffs destined to feed the over seven billion humans on the planet are produced by small household producers. This recognition led the FAO to declare the year 2014 as International Year of Family Farming [19]. A study made by the international nongovernmental organization GRAIN in 2015 [20] complemented the contribution of the FAO by adjusting the figures in terms of land tenure, confirming that small-scale farmers produce most of the food globally consumed by humans, but on the other side adding that they do so only on $25 \%$ of the total agricultural land surface.

This fact acquires particular importance in Latin America due to the social and cultural characteristics of its rural areas inhabited by 65 million peasants, of which between 40 and 55 million are part of various indigenous ethnic groups speaking over 1000 languages [21]. Within Latin America, Mexico has a special place in agricultural terms, because over half of its territory (over 104 million hectares) is owned by small-scale producers integrated in social farming units (ejidos and peasant communities) that are responsible for the largest surface used for production of basic grains and other foodstuffs in the country. This situation is the product of the early 20th century agrarian revolution in Mexico that became incorporated in the Mexican 1917 Constitution, which lead to the dismantling of large estates (haciendas) and the fractionation of the territory into thousands of productive units. Until 1910, the agrarian structure of Mexico included 5932 haciendas occupying 
$94 \%$ of the total land surface, 32,557 ranchers owning $5 \%$ of the land, and the remaining $1 \%$ of the land was in hands of peasant communities and native peoples [22]. This social transformation also caused the country to be re-indigenized by the return of a substantial portion of the territories to the originary peoples-descendants of the Mesoamerican civilization with over 7000 years of agricultural tradition-currently owing 28 million hectares of the national territory [23]. This repossession of land is seen in the demographic upturn experienced during the past 15 years by indigenous peoples, which passed from 10 to 12 million in the year 2000 to over 25 million in 2015, making Mexico the country with the largest indigenous population in the American continent. At present, 31,500 ejidos and peasant communities own $54 \%$ of the total agricultural land of Mexico, which added to $35.7 \%$ of that total owned by 1.6 million small-scale landholders (most owning five hectares or less), accounts for $90 \%$ the country's territory being in hands of small-scale farmers [24].

Based on a study of current sustainable projects in Mexico, carried out by Toledo and Ortiz-Espejel [25], which offers a general perspective of the number and distribution of potential agroecological projects in Mexico, we will briefly review three of the most important agroecological production sectors in the country: maize production in milpas, shade-grown coffee, and honey production.

\section{Agroecology and Maize Production}

The most frequent and extended food producing system in rural landscapes of Mexico is the milpa (name derived from the Nahuatl words, milli, crop field and pan, on top of), a polyculture system with at least 9000 years of antiquity, which has maize as its main crop. Mexico is the repository of over 65 races of maize cultivated throughout the country that are the result of the millenarian coevolution between the cereal and Mesoamerican indigenous peoples and peasants, which traditionally managed, domesticated, diversified, and enhanced it in a process that continues to this day. In Mesoamerica, the Mexican Neolithic Revolution not only implied the invention of maize and nearly 200 other crop plants [26], but also the creation of the milpa in which numerous and varied annual, biannual, semi-domesticated, and tolerated plant species coexist in crop associations that depend on the biocultural regions of farmers. Currently, native seeds of maize are sown by two and a half million peasant households in medium to low productivity lands extending over one half of the total agricultural surface of Mexico and in production units of less than five hectares [27] Supplemented by other crops of the milpa-such as beans, squash, chili pepper, amaranth, and several species of edible greens (quelites) - maize continues to be the staple foodstuff of Mexicans.

Genetic contamination of native maize was discovered during the past two decades in indigenous territories and peasant communities of Mexico [28-33], exhibiting the potential arrival of genetically modified maize to Mexico and triggering a countrywide upraise of unprecedented social resistance [34], a social movement that receives strong influence from agroecological principles. This resistance movement has been nurtured at urban, peasant, scientific, cultural (intellectual and artistic) national, regional, and local scales, and indigenous peoples' claims that were synthesized in the slogan "without maize, there is no country" (in Spanish "sin maiz no hay pais"). Within the context of this social struggle, a diverse array of indigenous and peasant communities have locally undertaken actions adapted to their own cultural and environmental circumstances, which led to the elaboration and popularization of political discourses and practices in which maize appears as the emblematic icon of their demands. Considering the ongoing process of erosion of the Mesoamerican agro-biodiversity taking place in territories of indigenous and peasant communities, their claims are ultimately expressing rejection of industrialized agriculture and transgenic biotechnology, opposition to local effects of the global market, disapproval of the health risks implied in industrialization, genetically modified crops, and global trade practices, and the struggles for territorial defense of indigenous peoples, and for achieving local food sovereignty.

Given that, in the case of maize, the spread and multiplication of the agroecological paradigm is inseparable from the uprising resistance to the threat represented by genetically modified varieties, 
in the following sections we briefly examine the agroecological and social aspects of five projects considered as emblematic, each one with its own particularities and features in common.

\subsection{Center for Integral Small Farmer Development in the Mixteca (CEDICAM)}

The CEDICAM (in its Spanish acronym) is an organization formed two decades ago by indigenous small farmers from the Mixteca Alta region in the state of Oaxaca, one of the zones most affected by soil erosion in the country. The projects of CEDICAM aimed at reconstructing the milpa with an agroecological approach and a farmer-to-farmer structure, for which the organization was granted the Goldman Environmental Prize in 2008 in recognition of its actions favoring environmental restoration and sustainable agriculture. Centered in Nochixtlán, Oaxaca, and led by Jesús León Santos, the center carries out agroecological and landscape restoration activities in 10 communities in the region including building, restoring, and maintaining trenches and barriers for terrace agriculture, production, and application of organic fertilizers and green manures, integrated pest management, storage and selection of native crop seeds, promotion of family gardens, use of rustic greenhouses, use of polyculture and crop rotation in milpas, and organization of maize and milpa fairs.

\subsection{Network for Sustainable Agricultural Alternatives (RASA)}

RASA (in its Spanish acronym) is an initiative gathering peasants, indigenous people, women, consumers, urban population, technical advisors, nongovernmental organizations, and universities. Its objective is encouraging agroecology and popular education among nearly 100 rural households in 20 localities from an equal number of municipalities of the state of Jalisco. RASA's activities are implemented by means of programs focused on training of local promoters, participation in agroecological production, caring for agro-diversity, strengthening of fair trade supply chains, and implementation of critical pedagogical approaches and participative research activities. In past years, RASA has organized maize and milpa fairs in several communities.

\subsection{Project of Integral Rural Development Vicente Guerrero, A.C. (GVG)}

The GVG (in its Spanish acronym) is a civil association responsible for one of the most successful initiatives of sustainable farming in the country developing on the slopes of the volcanoes forming the watershed dividing the valleys of Puebla-Tlaxcala and the valley of Mexico. The over 38 years of experience of the GVG allows the association to sustain a regional movement of resistance to genetically modified crops and of defense of local native maize varieties. The GVG involves dozens of peasant communities that have implemented alternative rural development strategies resulting in the improvement of the quality of life of their members, positive impact on local rural landscapes, establishment of regional repositories of genetically healthy improved native seeds, and organization during the past 17 years of maize and milpa fairs. The GVG has proposed legislation avoiding sowing of genetically modified crops in the state of Tlaxcala, which was approved by the state's congress.

\subsection{Union of Organizations of the Sierra Norte de Juárez in Oaxaca (UNOSOJO)}

The UNOSOJO (in its Spanish acronym) was integrated at the beginning of the present decade in the Sierra de Juárez-where Quist and Chapela [28] found the first evidence of transgenic contamination of native maize - with the objective of defending local native maize varieties against introduction of genetically modified crops. UNOSOJO works with 19 Zapotec communities involved in attempting to put an end to contamination of native maize by genetically modified maize, creating regional native seed banks, and achieving food sovereignty. The milpa fairs organized by the UNOSOJO represent a social platform for coordinating similar collective resistance movements. 


\subsection{Totonac Nahuatl Indigenous Union (UNITONA)}

The UNITONA (in its Spanish acronym) is a coalition of indigenous organizations born in the year 2001 in response to the discovery of transgenic contamination of native maize in 12 municipalities of the Sierra Norte de Puebla region. Hundreds of small farmers, nongovernmental organizations, and religious associations organized for rejecting the potential effects of genetic contamination of maize in their parcels and foodstuffs, implementing actions under the program Communitarian Defense of Biodiversity. Permanent monitoring is conducted to prevent biopiracy at the same time that communitarian native seed banks are created for preserving local germplasm and for systematizing information about native varieties of maize and other crops. The UNITONA organizes workshops and communitarian assemblies for political discussions about conservation of native maize varieties and about the threats currently faced by maize. The Union has joined other similar movements in Mexico and has also established international links with Via Campesina and the Landless Workers Movement of Brazil. In 2004, the UNITONA released the Manifest in Defense of Maize expressing its opposition to establishment of experimental fields in their territories for genetically modified maize and to import of such varieties, arguing that such events would seriously damage the autonomy of Totonac and Nahuatl peoples and create health risks to their communities.

\subsection{National Association of Commercializing Enterprises of Agricultural Producers (ANEC)}

The ANEC (in its Spanish acronym) is unique because of being an autonomous, independent, democratic, and plural organization with national scale organization, and also noticeable for going beyond agricultural production into the market, finding funding and credits, and technological innovation. The association was formed in 1995, currently including 219 companies in 19 states of Mexico representing nearly 60,000 small and medium scale producers of basic grains, mostly of maize, sorghum, wheat, bean, and rice. Its main goals are food sovereignty, reappraisal, development of small and medium scale farming, and sustainable agriculture. The association is also involved in agricultural practices that protect and conserve the natural properties of soil, water, and the environment in order to produce healthy foodstuffs, which is achieved by means of combining knowledge from small farmers, scientists, and technicians based on continuing education.

Among other important actions of the ANEC.- whose present slogan is change the Mexican land's production paradigm - two are noteworthy, the Value to the Peasant Initiative started in 2015 integrated by non-governmental and small farmer organizations, and the Model of Peasant Agriculture with Integrated Knowledge, which combines scientists' and farmers' knowledge to produce healthy crops without using agrochemicals, at higher yields, and at a lower cost. For celebrating its 20th anniversary the ANEC financed and organized the First International Meeting of Peasant Agriculture and Agroecology in America with the goal of discussing food sovereignty, dialogue of knowledge, and public policies, among other topics, which was the most relevant meeting of its kind ever to take place in Mexico, gathering over 300 participants from 16 countries.

\subsection{The Maize Fairs}

Maize fairs (in Spanish sometimes called fiesta del maíz) represent the revival of ritual activities strengthening the eroded communitarian links, giving sense to communitarian life and dignity, their numbers having substantially increased in recent years in territories in resistance. Maize fairs are held in at least three relevant phases of the cropping cycle of maize: after seeds are blessed and sown (February to March), during invocation for rain (May), and before the harvest (October to November). We counted 20 fairs celebrated during the year 2009, a number which increased to 80 by 2016 and presently growing in proportion with the intensification of conflicts and the increasing social consciousness of being men and woman made of maize. Activities in fairs include seed exchange between small farmers from the locality and from other states and regions, recovery of local culinary traditions, exhibits of farm implements and old photographs, talks about the consequences of transgenic seed 
use and about who promotes them, seed blessing, and staging of plays and film exhibitions, among others. Fairs are learning spaces and an opportunity for consolidation of social and communitarian connections, which undoubtedly are political activities.

From 2002 to 2015, native seed fairs took place in 44 localities in the Yucatan Peninsula-both in rural communities and in formal and informal academic centers-providing peasant households with an informal supply source of seeds of maize and other crops cultivated in their milpas and family gardens. This exchange additionally stimulates the exchange of knowledge about maize diversity, in situ conservation, and participative crop improvement [35].

In the states of Tlaxcala and Puebla, maize and milpa fairs have noticeably increased in number and in complexity. In Tlaxcala, more than 1000 people attended the 19th annual maize fair of the organization Vicente Guerrero, A.C., held on March of 2016, while nearly a dozen of maize fairs were organized in Puebla in the last two years, particularly in the Sierra Norte region of the state. Some 10 maize and milpa fairs were held in Chiapas in recent years, basically organized by women and native peoples and in connection with alternative markets.

\subsection{Alternative Markets: The Tianguis}

The emergence of alternative markets, which in Mexico are called tianguis after the Nahuatl word for market (tianquiztli), expanded exponentially since the first alternative tianguis inaugurated in the year 1996. More than 60 alternative ecological or agroecological exchange markets took place throughout Mexico by the end of 2014 and currently that figure is possibly of $70[36,37]$ located in 22 Mexican states. Alternative tianguis are an important connection between ecological and agroecological producers and the sectors of society concerned about healthy diet, fair trade, and establishing solidarity links with other sectors of society. These alternative markets are a means for establishing solidarity networks between different social actors with cultural, ideological, and political affinities, agroecological milpa systems, and maize and milpa fairs, which are exemplified by the case of the Mayab Tianguis in the state of Quintana Roo [38].

Local alternative markets under a number of denominations end up becoming closing nodes of increasingly circuit forming parts of a varied network of producers of healthy or agroecological commodities from many contrasting regions. The knowledge shared by consumers of alternative markets and the cultural and educational activities organized in them go beyond ordinary commercial transactions. Many alternative markets in Tlaxcala, Veracruz, Puebla, Oaxaca, Chiapas, and the Yucatan Peninsula are directly connected to agroecological movements of resistance to transgenic maize authorization, and in the above-mentioned states plus the State of Mexico and Jalisco, alternative markets are associated with maize and milpa fairs.

\subsection{Agroecological Defense of Maize at National and International Levels}

The emergence of local and regional agroecological projects, such as the above-mentioned emblematic cases, has in highly creative and variegated ways nourished national level initiatives embracing political and cultural defenses of native maize against introduction of genetically modified maize. Over more than 15 years all these initiatives have reached a substantial advance in terms of their demands and claims having international consequences. Constructed as multi-scalar nested networks linking the local and regional with the national and global, initiatives for the defense of maize agglutinate collective efforts by means of the committed interaction of diverse social actors in the rural and urban space. From the beginning of the century, the convergence of communities and peasant organizations in creative resistance with civil organizations, social movements, middle education schools and universities, academic centers, scientists, artists, intellectuals, politics, lawyers, and social promoters, has created a national movement that-implicitly or explicitly-has expanded and strengthened the Mexican agroecological movement.

The first of the main initiatives needing mention is the National Network in Defense of Maize, initiated in 2002 responding to contamination of native maize with transgenes and by 
2013 agglutinating communities and organizations from 12 states. The network is structured as a permanent dialogue and action platform for indigenous and peasant communities and hundreds of social organizations, acting in solidarity and forming a front of social struggle not only against genetically modified maize, but also for territorial and alimentary autonomy. A second initiative deserving mention is the campaign known as "Without maize, there is no country". Created in 2007, it has formed together with other civil associations a nested network of 300 social initiatives in defense of native maize, agroecology, and alimentary sovereignty. The main accomplishment of this movement was stopping the commercial release of genetically modified maize in Mexico. This was achieved by means of a collective demand filed three years ago by 53 individuals and organizations-including civil associations, peasants, indigenous communities, scientists, artists, intellectuals, and environmentalists-against the Mexican government's SAGARPA and SEMARNAT, and against the main genetically modified seed companies Monsanto, Syngenta, Pioneer, DuPont, and Dow (Table 1).

Table 1. Main features of five initiatives on agroecological production of maize in Mexico.

\begin{tabular}{|c|c|c|c|c|}
\hline Emblematic Cases & $\begin{array}{c}\text { Foundation and } \\
\text { Years of } \\
\text { Experience }\end{array}$ & Area of Action & $\begin{array}{c}\text { Number of } \\
\text { Interactions with } \\
\text { Academic Centers }\end{array}$ & $\begin{array}{c}\text { Number of } \\
\text { Interactions with } \\
\text { Grassroots Movements }\end{array}$ \\
\hline $\begin{array}{l}\text { Project of Integral Rural } \\
\text { Development Vicente Guerrero, } \\
\text { A.C. (GVG), Tlaxcala. }\end{array}$ & 1980,37 years & $\begin{array}{l}\text { Tlaxcala } 6 \\
\text { municipalities } \\
23 \text { localities }\end{array}$ & 8 & 10 \\
\hline $\begin{array}{l}\text { Totonac Nahuatl Indigenous } \\
\text { Union (UNITONA), Puebla. }\end{array}$ & 2000,17 years & $\begin{array}{c}\text { Puebla } \\
29 \text { municipalities }\end{array}$ & 4 & 9 \\
\hline $\begin{array}{c}\text { Center for Integral Small Farmer } \\
\text { Development in the Mixteca } \\
\text { (CEDICAM), Oaxaca }\end{array}$ & 1997, 20 years & $\begin{array}{l}\text { Oaxaca Mixteca } \\
\text { Region } 22 \text { villages }\end{array}$ & 4 & 3 \\
\hline $\begin{array}{c}\text { Network for Sustainable } \\
\text { Agricultural Alternatives } \\
\text { (RASA), Jalisco }\end{array}$ & 1999,18 years & $\begin{array}{c}\text { Jalisco } \\
20 \text { municipalities } \\
20 \text { localities }\end{array}$ & 3 & 3 \\
\hline $\begin{array}{l}\text { National Association of } \\
\text { Commercializing Enterprises of } \\
\text { Agricultural Producers (ANEC) }\end{array}$ & 1995,22 years & $\begin{array}{c}\text { National estates } 29 \\
60,000 \text { members }\end{array}$ & 2 & 1 \\
\hline
\end{tabular}

\section{Agroecology and Coffee Production}

Coffee has been grown in Mexico since the 19th century, initially almost exclusively by medium to large-sized specialized estates owned by foreigners (and afterwards by Mexicans) in the states of Chiapas, Oaxaca, and Veracruz. The scenario of coffee production in Mexico began to be transformed by different events happening during the twentieth century, such as the agrarian revolution that dissected large estates, distributing land to thousands of ejidos and communities, and acknowledged the property rights of native peoples, and the expropriation by the government during the second World War of estates owned by Germans, Japanese, and Italian nationals. The period of statism followed, beginning in 1959 with the creation of INMECAFE, a governmental organism with a collectivistic inclination devoted to regulating coffee prices, providing incentives to national coffee producers in the form of credits and technical support, suppressing intermediarism (middlemen), and establishing thousands of coffee production and commercialization units in production regions [39]. INMECAFE was dismantled in the early 1990s after the retreat of the state and the advent of neoliberalism and its free trade policies. This resulted in a process of autonomous organization of hundreds of coffee producing cooperatives of peasants and indigenous communities. During these two decades, these cooperatives gradually adopted the principles of agroecology [40]. As a result, coffee production in Mexico is currently in the hands of owners of small properties $-90 \%$ of which own less than five hectares-organized in hundreds of cooperatives, an important proportion of which belong to indigenous peoples.

Production and export of coffee has been a highly relevant economic activity in Mexico, which together with India occupies the fifth place among coffee producers in the world and according to 
FAO [41] produces nearly one-fifth of the global production of coffee and has being leading the world's production of organic coffee for nearly two decades. Coffee is produced in Mexico according to suitable elevations going from 600 to 1200 m.a.s.l., along the transitional zone between the tropical and the temperate ecological belts. Coffee producing regions are among the richest in flora and fauna in Mexico and are considered as strategic for conservation of biodiversity [42]. According to the inventory of coffee producers in Mexico (the PNC by its Spanish acronym), during the 2011-2012 agricultural cycle there were 542 thousand producers growing coffee on 762 thousand hectares [43]. The states of Chiapas, Veracruz, Puebla, and Oaxaca produce $94 \%$ of the total production of coffee, containing $85 \%$ of the planted surface and $83 \%$ of the coffee producers in the country. Nearly $80 \%$ of the production of coffee in Mexico is exported.

Mexican organic coffee is produced without the use of agrochemicals and under the shade of a forest canopy, which helps to preserve the natural habitat and, consequently, biodiversity, soil quality, and water runoff. According to recent statistics, Mexican organic coffee was produced by some 128,000 small-scale producers, most of them belonging to indigenous cooperatives and peasant organizations in the states of Chiapas, Oaxaca, Guerrero, Puebla, and Veracruz on a production area of about 350,000 hectares. Of the total coffee producers in the country, a minimum of 78,000 produce under certification rules [44]. Mexican organic coffee is imported to and consumed by countries such as the United States, Canada, France, the Netherlands, Germany, and Japan.

Production of coffee in Mexico has not only experienced an extraordinary expansion, but has also both motivated scientific research and stimulated the organization of small-scale farmers in cooperatives and in regional and state unions, therefore becoming the object of discussions about the meaning of agroecological strategies, focusing in the different modalities of coffee production. Coffee landscapes are man-made landscapes resulting from a complex set of environmental and social processes (for details see [42,45]) As in the rest of the world, in Mexico there are five main modes of producing coffee: (i) rustic polyculture and (ii) traditional polyculture, two shade-grown coffee systems established under a multilayered and multispecies canopy of native trees that generally are grown by indigenous, small-scale growers; (iii) shaded commercial polyculture and (iv) shaded commercial monoculture, two coffee systems established under planted trees by either small- and medium-scale farmers, or large-scale owners highly involved in the production of specialized cash crops; and (v) sun coffee system, a monoculture system utilizing chemical fertilizers and pesticides and generally practiced by major landowners. Each of these five types of coffee systems reflects specific combinations of biological, ecological, cultural, agricultural, and social factors. The two traditional shaded coffee agroforests (rustic polyculture and traditional polyculture), but especially traditional polyculture also called coffee gardens, represent an advanced stage of human manipulation of the native forest architecture and composition. Coffee gardens are a sort of man-made forest, which can function as an important refuge for biodiversity, predominantly of birds, mammals, flowering plants, and insects.

In the discussion of which system of coffee production is more agroecological, clearly rustic polyculture and traditional polyculture are the most appropriate, because the forest canopy is conserved which is also modified by suppression of certain species for shade management and to which species having market value are introduced. The agroecological suitability of coffee polyculture systems is not only based on maintenance of the forest canopy and a certain level of biodiversity, but also because of the environmental services it offers such as carbon capture, soil erosion prevention, climate stabilization, and maintenance of a pool of pollinators. Sun coffee is the anti-ecological extreme and the systems introducing a planted canopy are intermediate in agroecological suitability. To date, no consensus has been reached regarding the real meaning of agroecological coffee production. Instead there is an ample range of definitions and interpretations under terms such as ecological coffee, organic coffee, sustainable coffee, environmentally friendly coffee, bird friendly coffee, shade coffee, and others, all preferred by the various coffee markets in Europe, North America, and Japan.

Based on our own review, it is possible to distinguish some modalities of scientific research about coffee production: (a) research focused on generating general technological, economical, 
commercial, and social knowledge addressed to all sectors of coffee production (estates, medium-sized producers, and peasant cooperatives), as is the case of the Institute of Ecology at Veracruz; (b) research addressing specific cooperatives with their participation (case of CIEDAC in Chiapas); and (c) research aiming at strengthening political autonomy of communities (specifically of Zapatista regions), as is the case of UNITERRA in Chiapas. To the above are added the research initiatives of each coffee cooperative, especially of the largest and better consolidated ones, in which technological, organizational, and social innovations are the result of the interaction between researchers, technicians, and producers by means of a dialogue of knowledges and participative scientific research approaches, as in the cases of Tosepan Titataniske in Puebla, the UCIRI in Oaxaca, and MAJOMUT in Chiapas. In these initiatives, the organizational consolidation of small-scale producers has played a central role, producers achieving the creation of regional, state, and national unions after several decades of effort. This is the case of the National Alliance of Coffee-Producing Organizations (CNOC by its Spanish acronym), which is a network of 126 independent organizations in Mexico that works to benefit some 75,000 small-scale, predominantly indigenous producers, who generate most of the organic coffee harvest. This organizational umbrella includes advisers and scientists, technicians, and nongovernmental organizations for promoting the social well-being of small-scale producers and their households by means of empowering local organizations, advocating environmental protection, and promoting certified organic coffee grown in traditional shaded agroforests (Table 2).

Table 2. Seven agroecological research centers of coffee production in Mexico.

\begin{tabular}{|c|c|c|c|c|}
\hline Research Institution & Localization & $\begin{array}{c}\text { Date of } \\
\text { Foundation }\end{array}$ & Scale of Action & Web Site \\
\hline $\begin{array}{l}\text { CIIDRI Interdisciplinary } \\
\text { Research Center for } \\
\text { Rural Development }\end{array}$ & $\begin{array}{l}\text { Universidad } \\
\text { Autónoma } \\
\text { Chapingo, } \\
\text { Texcoco }\end{array}$ & 2008 & National & https://chapingo.mx \\
\hline $\begin{array}{l}\text { CENACAFE National } \\
\text { Center for the Research, } \\
\text { Innovation and } \\
\text { Technological } \\
\text { Development of Coffee }\end{array}$ & $\begin{array}{l}\text { Universidad } \\
\text { Autónoma } \\
\text { Chapingo, } \\
\text { Huatusco, } \\
\text { Veracruz }\end{array}$ & 2015 & $\begin{array}{l}\text { Cooperatives and } \\
\text { private owners of } \\
\text { Central veracurz }\end{array}$ & http://www.cenacafe.org.mx/ \\
\hline $\begin{array}{c}\text { CAFECOL Coffee } \\
\text { Agroecological Center }\end{array}$ & $\begin{array}{c}\text { Xalapa, } \\
\text { Veracruz }\end{array}$ & 2016 & National & www.cafecol.mx \\
\hline $\begin{array}{l}\text { CICADES International } \\
\text { Center on Coffee and } \\
\text { Sustainable Development }\end{array}$ & $\begin{array}{l}\text { Ixhuatlán, } \\
\text { Veracruz }\end{array}$ & 2003 & Regional & $\begin{array}{l}\text { https:/ / centrocicadesdotorg. } \\
\text { wordpress.com }\end{array}$ \\
\hline CAFÉ in RED & $\begin{array}{l}\text { Instituto de } \\
\text { Ecología, } \\
\text { Xalapa, } \\
\text { Veracruz }\end{array}$ & 2016 & National & $\begin{array}{l}\text { www.ef.inecol.edu.mx/ } \\
\text { cafeinred }\end{array}$ \\
\hline $\begin{array}{l}\text { CIDECI-UNITIERRA } \\
\text { Universidad de la Tierra } \\
\text { (Earth University) }\end{array}$ & $\begin{array}{c}\text { San Cristobal } \\
\text { de las Casas, } \\
\text { Chiapas }\end{array}$ & 2001 & $\begin{array}{l}\text { Cooperatives and } \\
\text { communities of the } \\
\text { EZLN (Zapatista Army } \\
\text { of National Liberation) }\end{array}$ & http://seminarioscideci.org/ \\
\hline $\begin{array}{l}\text { CIEDAC Center on } \\
\text { Indigenous Rights }\end{array}$ & $\begin{array}{l}\text { Chilón, } \\
\text { Chiapas }\end{array}$ & 1992 & $\begin{array}{l}\text { Municipalities of } \\
\text { Chilón, Sitalá, Yajalón, } \\
\text { Pantelhó, Salto de } \\
\text { Agua, Palenque and } \\
\text { Simojovel, in Chiapas }\end{array}$ & http://www.cediac.org \\
\hline
\end{tabular}

\section{Agroecology and Honey Production}

The Yucatan Peninsula - where 63\% of the total inhabitants are of Mayan descent-is the most important honey production region of Mexico. Before Spanish conquest, Maya beekeepers collected honey and wax from the native stingless bees (Melipona beecheii), which in Maya were called Koolelkab and Xuna'ankab, meaning honey goddess. European beehives (Apis mellifera) were introduced to the Yucatan Peninsula in the early 20th century mostly by private entrepreneurs, and-as in the case of 
coffee planting — the Maya communities adopted beekeeping, a few decades later becoming national leaders in number of honey producers. According to CONABIO [46], the region presently has about 40,000 beekeepers organized in 162 cooperatives. The honey produced by small farmers in systems with high diversity pivoting around the milpa is mostly exported to the European Union (85\%).

Despite organic honey being produced by only $10 \%$ of the owners of commercial beehives, beekeeping is generally considered ecologically acceptable because it does not threaten the region's tropical forests-rich in species of melliferous plants. The authorization by the Mexican Government for planting of transgenic soybean in the Yucatan Peninsula was met with a similar response of resistance from local small farmers as the one encountered by transgenic maize throughout the country. Because transgenic soybean pollen was found in honey exported to the European Union affecting future exports of the product from the region, thousands of honey producers launched a campaign for removing the official authorization for cultivation of transgenic soybean in the region - signed by over 63,000 people- and filed two legal demands that were favorably resolved, reverting the authorization for transgenic soybean production in the region. As a result, a new law was established prohibiting the cultivation of transgenic crops in the state of Yucatan.

\section{Discussion}

Highly complex processes generating multiple synergies at various and different scales and rhythms, are the result of interactions between scientific research, technological innovation, and the social, political, and cultural action and activism held by mainly small-scale farmers movements, those are the three agroecological dimensions, or the agroecological holy trinity. This was confirmed by the review made all along the various sections of this paper. There exist countless feedback examples in the reviewed three production systems (maize, coffee, and honey). In such cases, scientific research not only stimulated technological innovation, or social and political action, but the social action conveys and drives scientific and technological production in new paths, namely in new approaches and knowledge production modes of conception. In the case of maize, each one of the five emblematic reviewed examples reveal that scientific and technological research was conducted by the agroecological paradigm in an intimate relation with the farmers' organizations action and participation (see Table 1). As a counterpart, the indigenous small-scale coffee producers' vigorous movement that emerged and expanded within the last 40 years, has generated diverse and different research approaches conducted by new academic centers and scientists guiding innovative projects (Table 2). In the case of honey, thousands of Mayan household beekeepers have benefited from countless research findings on melliferous flora [47,48], its cycles and offers [49], the effects of honey contamination by GM soya bean [50], and honeybee environmental services [51]. For example, ECOSUR (The South Border College or El Colegio de la Frontera Sur), a prestigious research and postgraduate education center offers a Diploma Program on Organic and Agroecological Apiculture, since more than 10 years ago. This diploma course offers training on apiarian and floral resources management, certification procedures, integrated healthcare, GM contamination avoiding measurements, and organizational and administration polices and procedures. On the other side of this spectrum, grassroots and political organizations at national level, such as the CNOC (The National Coordination of Coffee Producers' Organizations), or the UFIC (The Indigenous and Peasant Unit Force), have embraced agroecology as part of their practical philosophies and as their main struggle objectives (see Table 2).

\section{Concluding Remarks}

As an emerging approach, political agroecology forms some new ways of constructing linkages between knowledge, power, and practice. Scientific knowledge and its correlated technologies have normally been thought as supporting political and economic hegemonic forces. Fortunately, the fields of science and technology studies made considerable progress toward illuminating relationships between science, and political, economic, and social powers during the past two decades. Modern science and its technological innovation (or technoscience) both embed and are embedded in social 
realities, institutions, representations, and discourses, because the ways of knowing the world (ontologies) are inextricably linked to the ways in which people seek to organize it and control it. Rural producers and their organizations (communities, cooperatives, unions, etc.), together with scientists, technicians, NGOs and other actors co-produce new and hybrid alternative knowledge that gives visibility and legitimacy to local actors. During the appropriation of nature, political agroecologists (which in reality form a sort of a consortium linking a wide variety of social actors) are co-producers of emerging emancipatory realities in ontological, cognitive, and practical dimensions, but not just knowledge. In the last stance, political agroecology is a power force pushing towards knowledge democratization, ecologically friendly practice, social equality, and productive efficiency.

Agroecology in Mexico expands as a silent social and political movement led by indigenous and mestizo peasant communities including hundreds of thousands (maybe even millions) of men and women producing on a considerable proportion of cropland throughout the country. A good part of the above-mentioned agroecological projects are active and creative forms of resistance against the agroindustrial model, agribusinesses, and the neoliberal agrarian policies implemented for more than three decades by the Mexican government. These initiatives-built from the ground up and interlinked at the regional, state, nation, and global scales-are in some way rooted in the lengthy tradition of Mesoamerican agriculture within a country with high biocultural megadiversity. Sustentation of production under agroecological principles of maize in milpas, coffee, and of honey are, likewise, a sign of a millenarian and deep knowledge of a complex and capricious nature to which it needed to be adapted. Such co-evolutionary systems have enabled long-living ecological, agronomic, and cultural adaptations, because of which those who adopt them are highly resilient social sectors in constant hybridization. Overall, what becomes revealed is a way towards sustainability, understood as improvements in the quality of life of social actors, ecologically adequate management of nature and its resources, self-management, autonomy, and self-sufficiency of agrarian social groups.

Acknowledgments: We greatly thank Sergio Zárate for the translation into English of the original text, and Pablo Alarcón-Chaires for editorial assistance. The wise opinions and criticisms of two anonymous reviewers were crucial for enhancing the paper.

Author Contributions: V.M. Toledo and N. Barrera-Bassols conceived and designed the content of the paper. Both conducted the detailed review of literature.

Conflicts of Interest: The authors declare no conflict of interest.

\section{References}

1. Kimbrell, A. (Ed.) The Fatal Harvest Reader: The Tragedy of Industrial Agriculture; Foundation for Deep Ecology, Island Press: Washington, DC, USA, 2002; p. 384.

2. Wezel, A.; Bellon, S.; Doré, T.; Francis, C.; Vallod, D.; David, C. Agroecology as a science, a movement and a practice. A review. Agron. Sustain. Dev. 2009, 29, 503-515. [CrossRef]

3. Sevilla-Guzmán, E. Woodgate Agroecology: Foundations in agrarian social thought and sociological theory. Agroecol. Sustain. Food Syst. 2013, 37, 32-44.

4. Vandermeer, J.; Perfecto, I. Complex traditions: Intersecting theoretical frameworks in agroecological research. Agroecol. Sustain. Food Syst. 2013, 37, 76-89. [CrossRef]

5. Rosset, P.M.; Martínez-Torres, M.E. Rural social movements and agroecology: Context, theory, and process. Ecol. Soc. 2012, 17, 17. [CrossRef]

6. Holt-Giménez, E. Campesino a Campesino: Voces de Latinoamérica Movimiento Campesino a Campesino para la Agricultura Sustentable; SIMAS: Managua, Nicaragua, 2008; p. 294.

7. Altieri, M.; Toledo, V.M. The agroecological revolution in Latin America: Rescuing nature, ensuring food sovereignty and empowering peasants. J. Peasant Stud. 2011, 38, 587-612. [CrossRef]

8. Toledo, V.M. La agroecología en Latinoamérica: Tres revoluciones y una sola transformación. Agroecología 2012, 6, 37-46.

9. De Molina, M.G. Agroecology and Politics. How to Get Sustainability? About the Necessity for a Political Agroecology. Agroecol. Sustain. Food Syst. 2013, 37, 45-59. 
10. Méndez, E.V.; Bacon, C.M.; Cohen, R.; Gliessman, S.R. (Eds.) Agroecology: A Transdisciplinary, Participatory and Action-Oriented Approach; CRC Press: Boca Raton, FL, USA, 2015.

11. De Wit, M.M.; Iles, A. Toward Thick Legitimacy: Creating a Web of Legitimacy for Agroecology. Elementa 2016, 4, 000115.

12. Méndez, E.V.; Bacon, C.M.; Cohen, R. Agroecology as a Transdisciplinary, Participatory, and Action-Oriented Approach. Agroecol. Sustain. Food Syst. 2013, 37, 3-18.

13. Guzmán-Casado, G.I.; Alonso-Mielgo, A.M. La investigación participativa en agroecología: Una herramienta para el desarrollo sustentable. Ecosistemas 2007, 16, 24-36.

14. Fals-Borda, O.; Rahman, M.A. Action and Knowledge, Breaking the Monopoly by Action Research; Rowman \& Littlefield Publishers: Lanham, MD, USA, 1991.

15. Jasanoff, S. (Ed.) States of Knowledge: The Co-Production of Science and Social Order; Routledge: London, UK, 2004.

16. Conde, M. Activism mobilising science. Ecol. Econ. 2014, 105, 67-77. [CrossRef]

17. Netting, R.M.C. Smallholders, Householders: Farm Families and the Ecology of Intensive, Sustainable Agriculture; Stanford University Press: Stanford, CA, USA, 1993; p. 389.

18. Toledo, V.M.; Barrera-Bassols, N. La Memoria Biocultural: La Importancia Ecológica de las Sabidurías Tradicionales; Icaria Editorial: Barcelona, Spain, 2008.

19. Food and Agriculture and Originzation of the United Nations (FAO). La Innovación en la Agricultura Familiar. 2014. Available online: http:/ /www.fao.org/3/a-i4036s.pdf (accessed on 12 August 2016).

20. GRAIN. 2014. Available online: https://www.grain.org/es/article/entries/4956-hambrientos-de-tierra-lospueblos-indigenas-y-campesinos-alimentan-al-mundo-con-menos-de-un-cuarto-de-la-tierra-agricolamundial (accessed on 1 June 2016).

21. Toledo, V.M. Latinoamérica como laboratorio socio-ambiental: Pueblos indígenas, memoria biocultural y cambio civilizatorio. In Un Viaje por Las Alternativas al Desarrollo; Eschenhagen, M.L., Ed.; Universidad Pontificia Bolivariana y Universidad de Rosario: Bogotá, Colombia, 2013; pp. 27-36.

22. Córdova, A. La ideología de la Revolución Mexicana; ERA Editorial: Cuauhtémoc, Mexico, 1972.

23. Boege, E. El Patrimonio Biocultural de los Pueblos Indígenas de México; Instituto Nacional de Antropología e Historia y Comisión Nacional para el Desarrollo de los Pueblos Indígenas: Tlacopac, Mexico, 2008; p. 344.

24. Robles-Berlanga, H. Valor al campesino, vida, nutrición y riqueza para México. La Jornada Campo 2015, 95, 4-5.

25. Toledo, V.M.; Ortíz-Espejel, B. Regiones que Caminan hacia la Sustentabilidad; Universidad Iberoamericana y CONACyT: Ciudad de México, Mexico, 2015.

26. Casas, A.; Otero-Arnaiz, A.; Pérez-Negrón, E.; Valiente-Banuet, A. In situ Management and Domestication of Plants in Mesoamerica. Ann. Bot. 2007, 100, 1101-1115. [CrossRef] [PubMed]

27. Turrent, A.; Wise, T.A.; Garvey, E. Factibilidad de Alcanzar el Potencial Productivo de Maíz en México; Global Development and Environment Institute, Mexican Rural Development Research Num. 24. Tufts University: Boston, MA, USA, 2012.

28. Quist, D.; Chapela, G. Transgenic DNA introgressed into traditional maize landraces in Oaxaca, Mexico. Nature 2001, 414, 541-543. [CrossRef] [PubMed]

29. Ezcurra, E.; Ortiz, S.; Soberón, J. Evidence of gene flow from transgenic maize to local varieties in Mexico. In GMOs and the Environment, Proceedings of the International Conference, Cambridge, MA, USA, 4-6 June 2002; OECD: Paris, France, 2002; pp. 289-295.

30. Cleveland, D.; Soleri, D.; Aragón Cuevas, F.; Crossa, J.; Gepts, P. Detecting (trans)gene flow to landraces in centres of crop origin: Lessons from the case of maize in Mexico. Environ. Biosaf. Res. 2005, 4, 197-208. [CrossRef] [PubMed]

31. Serratos-Hernández, A.; Gómez-Olivares, J.L.; Salinas-Arreortua, N.; Buendía-Rodríguez, F.; Islas-Gutiérrez, F.; de Ita, A. Transgenic proteins in maize in the soil conservation area of Federal District, Mexico. Front. Ecol. Environ. 2007, 5, 247-252. [CrossRef]

32. Piñeyro-Nelson, J.; van der Heerwaarden, H.R.; Perales, R.; Serratos-Hernández, J.A.; Rangel, A.; Hufford, M.B.; Gepts, P.; Garay-Arroyo, A.; Rivera-Bustamante, R.; Álvarez-Buylla, E.R. Transgenes in Mexican maize: Molecular evidence and methodological considerations for GMO detection in landrace populations. Mol. Ecol. 2009, 18, 750-761. [CrossRef] [PubMed] 
33. Dyer, G.A.; Serratos-Hernández, J.A.; Perales, H.R.; Gepts, P.; Piñeyro-Nelson, A.; Chávez, A.; Salinas-Arreortua, N.; Yúnes-Naude, A.; Taylor, J.E.; Álvarez-Buylla, E.R. Dispersal of transgenes through maize seed systems in Mexico. PLoS ONE 2009, 5, e5734. [CrossRef] [PubMed]

34. Barrera-Bassols, N.; Astier, M.; Orozco, Q.; Boege, E. Saberes locales y defensa de la agrobiodiversidad. In Convivir Para Perdurar. Conflictos Ecosociales y Sabidurías Ecológicas; Álvarez Cantalapiedra, S., Ed.; Icaria / Antrazyt 34: Barcelona, Spain, 2011; pp. 289-310.

35. Dzib-Aguilar, L.A.; Ortega-Paczka, R.; Segura-Correa, J.C. Conservación in situ y mejoramiento participativo de maíces criollo en la Peninsula de Yucatán. Trop. Subtrop. Agroecosyst. 2016, 19, 51-59.

36. Escalona-Aguilar, M.A. Los Tianguis y Mercados Locales de Alimentos en México: Su Papel en el Consumo, la Producción y la Conservación de la Biodiversidad y Cultura. Ph.D. Thesis, Universidad de Córdoba, Córdoba, España, 18 March 2009.

37. García-Bustamante, R. Tianguis Alternativos Locales en México, Como Puntos de Encuentro Micropolítico. Ph.D. Thesis, Benemérita Universidad Autónoma de Puebla, Heroica Puebla de Zaragoza, Mexico, 2015.

38. Cazal-Ferreira, A.A.; Flores-Vega, V.; Mendoza-Lara, J.L. (Eds.) Agricultura Orgánica, una Apuesta al Desarrollo Sostenible Desde las Comunidades Mayas; Universidad del Caribe: Cancun, Mexico, 2014; p. 111.

39. Nolasco, M. Café y Sociedad en México; Centro de Ecodesarrollo: Altadena, Mexico, 1986.

40. Moguel, P.; Toledo, V.M. El Café en México, ecología, cultura indígena y sustentabilidad. Ciencias 1996, $43,40-51$.

41. Food and Agriculture and Originzation of the United Nations (FAO). Yearbook 2014; FAO: Rome, Italy, 2014.

42. Moguel, P.; Toledo, V.M. Biodiversity conservation in traditional coffee systems in Mexico. Conserv. Biol. 1999, 13, 1-12. [CrossRef]

43. SAGARPA. Padrón Nacional Cafetalero. 2012. Available online: http://www.sagarpa.gob.mx/Glosario/ Paginas/Padrón\%20Nacional\%20Cafetalero\%20(PNC).aspx (accesed on 18 September 2016).

44. Gómez-Tovar, L.; Gómez-Cruz, M.A.; Scwentesius-R, R. Los Aportes de la Agricultura Orgánica en México en el Contexto Actual. 2015. Available online: https://www.researchgate.net/publication/275331332 Bondades_y_Aportes_de_la_Agricultura_Organica (accessed on 27 October 2016).

45. Toledo, V.M.; Moguel, P. Coffee and sustainability: The multiple values of traditional shaded coffee. J. Sustain. Agric. 2012, 36, 353-377. [CrossRef]

46. Comisión Nacional para el Conocimiento y Uso de la Biodiversidad (CONABIO). Mieles Peninsulares y Diversidad; Corredor biológico Mesoamericano México: Sureste de México, Mexico, 2009.

47. Villanueva-Gutiérrez, R.; Roubik, D.W.; Porter-Bolland, L. Bee-Plant Interactions: Competition and Phenology of Flowers Visited by Bees. In Biodiversity and Conservation of the Yucatán Peninsula; Islebe, G.A., Ed.; Springer: Amsterdam, The Netherlands, 2015; pp. 131-152.

48. Porter-Bolland, L. La apicultura y el paisaje maya. Estudio sobre la fenología de floración de las especies melíferas y su relación con el ciclo apícola en La Montaña, Campeche, México. Estudios Mexicanos 2003, 19, 303-330. [CrossRef]

49. Flores-Guido, J.S. Flora Melífera. Biodiversidady Desarrollo Humano en Yucatán. Available online: http:/ / www.cicy.mx/Documentos/CICY/Sitios/Biodiversidad/pdfs/Cap7/05\%20Flora\%20melifera.pdf (accessed on 4 October 2016).

50. Villanueva-Gutiérrez, R.; Echazarreta-González, C.; Roubik, D.W.; Moguel-Ordóñez, Y.B. Transgenic soybean pollen (Glycine max L.) in honey from the Yucatán Peninsula, Mexico. Sci. Rep. 2014, 4, 4022. [CrossRef] [PubMed]

51. Landaverde-González, P.; Quezada-Euán, J.J.G.; Theodorou, P.; Murray, T.E.; Husemann, M.; Ayala, R.; Paxton, R.J. Sweat bees on hot chillies: Provision of pollination services by native bees in traditional slash-and-burn agriculture in the Yucatan Peninsula of tropical Mexico. J. Appl. Ecol. 2016. [CrossRef]

(C) 2017 by the authors; licensee MDPI, Basel, Switzerland. This article is an open access article distributed under the terms and conditions of the Creative Commons Attribution (CC BY) license (http:/ / creativecommons.org/licenses/by/4.0/). 